\title{
Conflicts and Mediation in a Multicultural Society: Psychological, Pedagogical and Sociological Aspects
}

\author{
Olga G. Smolyaninova* \\ Siberian Federal University \\ Krasnoyarsk, Russian Federation
}

Received 23.03.2020, received in revised form 01.09.2020, accepted 07.09.2020

\begin{abstract}
This article presents an analytical review of psychological, pedagogical and sociological aspects of conflict resolution with implementation of mediation in a multicultural society, which is based on the analysis and summary of the research presented in the articles of this issue. The theory and practice of conflict resolution, personality determinants of youth's behaviour, formats and models of training mediators for the system of education are analysed in multi-paradigm and interdisciplinary contexts and are the result of mutual efforts of teachers, practicing mediators, lawyers, psychologists and sociologists. The materials of this issue present research in several areas: models of training mediators, online mediation practices; professional and ethical standards of a mediator; sociological studies of social identities in the regions of the Russian frontier, sociological studies of the communicative and linguistic space of the Republic of Kazakhstan in the context of multilingualism; psychological and pedagogical studies of the personality determinants of young people; analysis of digital competencies of a mediator and a model of electronic support for undergraduates in the context of digital transformation.
\end{abstract}

Keywords: conflicts, multicultural society, mediation, online mediation, multilingualism, personality determinants, restorative approach, social identity, professional competence of a mediator, digital transformation.

Research areas: education; sociology.

Citation: Smolyaninova, O.G. (2020). Conflicts and mediation in a multicultural society: psychological, pedagogical and sociological aspects. J. Sib. Fed. Univ. Humanit. Soc. Sci., 13(9), 1428-1434. DOI: $10.17516 / 1997-1370-0653$.

\footnotetext{
(C) Siberian Federal University. All rights reserved

* Corresponding author E-mail address: smololga@mail.ru ORCID: 0000-0002-5597-6348
} 


\section{Introduction}

Failure to constructively resolve an insoluble conflict is a serious and often neglected problem for the modern society. The solution to many complex problems in the education system depends on finding more efficient ways to resolve these conflicts. One of these methods is mediation.

To date, no working method has been found for successive solution of multiculturalism problems in mediation.

According to Mark Davidheiser (2005) ${ }^{1}$, "Broad generalisations and simplistic conceptualisations about culture may work in some cases, but may be counterproductive in others. .... We have faced a difficult paradox. On the one hand, cultural differences can call into question the underlying assumptions (for example, beliefs about human nature, society, environment, etc.) that determine our practice. On the other hand, 'culture' is so dynamic and multidimensional that it is difficult to understand".

Ethnic diversity in schools is the major issue for education in most European countries. The cultural diversity of students and parents leads to changes, enables new forms of participation and requires the creation of new concepts, values and practices. Mediation processes play an important role in the settlement of social and political conflicts in order to preserve democracy in the globalised environment of the $21^{\text {st }}$ century.

The world is changing rapidly, and social institutions, methods of communication, and pedagogical reality in general are changing as well. Even though the period of distance learning organised by all educational institutions in the context of the pandemic was relatively short, pedagogical theory and practice, psychology of perception and communication experienced some turning points and, in essence, "a breakthrough in pedagogical reality" (Iamburg, 2020).

The purpose of this article is an analytical review of psychological, pedagogical and

\footnotetext{
Davidheiser, M. (2005). Mediation and Multiculturalism: Domestic and International Challenges. Available at: https:// www.beyondintractability.org/essay/mediation multiculturalism (accessed 21 August 2020).
}

sociological research in the field of conflict, mediation and intercultural communication among young people. In the materials of this issue of the Journal, the studies are presented in four thematic sections: 1) online models of training mediators and mediation practice; 2) professional and ethical standards of a mediator; 3) sociological research in the Russian regions and in the Republic of Kazakhstan; 4) psychological and pedagogical research of the personality determinants of young people. The authors of the studies include well-known scientists of Russia, representatives of various regions of Siberia: Krasnoyarsk Krai, Kuzbass, Irkutsk Region, Novosibirsk Region; as well as scientists and practicing mediators and professors from Moscow, St. Petersburg, and Kazakhstan.

\section{Analytical Review}

Let us look into details of each of the thematic sections of the analytical review. Different models of mediators' training are presented in the works by many Russian authors: Allakhverdova O.V. (Allakhverdova, 2012), Zhbankova N.V., Prokhorova O.A. (Zhbankova, Prokhorova, 2017), Belonogova E.V., Prokopyeva N.G (Belonogova, Prokopyeva, 2020), Shamlikashvili Ts.A. (Shamlikashvili, 2013), Smolyaninova O.G. (Smolyaninova, 2018) and many others.

Psychological complexity, a variety of participants in educational conflicts, different experience of introducing mediation into educational practice gives rise to different models of mediators' training. The Journal presents several models of training and retraining of mediators for the education system. The model of the regional system for mediators' training on the basis of the Kuzbass Center for Psychological, Pedagogical, Medical and Social Assistance "Health and Personal Development" (E. Belonogova, I. Sviridova) is quite inspiring. The authors outline the restorative approach and the paradigm of restorative justice. They provide a detailed description of the methodology and practice of training mediators based on restorative technique training, monthly methodological seminars for mediators and supervisors of reconciliation services in the 
region, supervision and intervision for leading restorative programmes; training programmes for volunteer mediators of school reconciliation services. The authors have 10 years of experience in training mediators and describe in detail the problems that beginners and practicing mediators face.

The model of professional retraining for the faculty of Siberian Federal University is presented in the work "Experience in implementing a practice-oriented program for retraining mediators for education and the social sphere" by E. Birkun and V. Korshunova.

The authors present the model for retraining mediators for education and social sphere of the Krasnoyarsk Krai, taking into account the needs of the multinational Siberian society. The retraining programme for teachers, psychologists and school mediators is implemented on the basis of the Centre for Mediation in Education of the School of Education, Psychology and Sociology of Siberian Federal University, in the network of educational organisations and professional communities. The basic principles of the conceptual model of retraining: continuity, supervision of professional activity, eventfulness of the educational process, organisation of mediation tests, continuity of the results of formal and non-formal education. The retraining course "Mediation. The Psychology of Conflict Management" has a modular format with the increase in the share of practical classes and organisation of research and project activities of students. As part of the retraining course, the development of mediation competence of participants was evaluated with measuring techniques of communicative, information-analytical, organisational, managerial and emotional competencies.

The article "Professional and ethical standards in the activity of a mediator: problems of implementation and control" by the researcher Anastasiia S. Arkhipkina from the East Siberian Branch of the Russian Academy of Justice, Irkutsk, discusses topical issues of professional and ethical standards in the activities of Russian mediators based on the methods of formal legal and comparative legal analysis. The author essentially describes the model of the mediator's profession revealing the requirements for the knowledge, skills and abilities of professional mediators. On the basis of the comparative legal analysis, the author for the first time analyses the basic ethical standards enshrined in the European Code of Mediators and the Code of Russian Mediators. It is noteworthy that the problems of implementing professional and ethical standards and organising the control over their compliance in the Russian Federation are described in detail. The author rightly notes that it is impossible to simply transfer foreign experience of implementing the professional and ethical standards of mediators and the control system into Russian reality.

I would like to add some judgments of my own regarding the difficulty of introducing professional and ethical standards of mediators into practice associated with the diversity of cultural and social differences among young people, age and status differences of the parties involved in educational conflicts in the Russian Federation. Intercultural issues exacerbate the need to develop new models and upgrade existing mediator training programmes, expand the forms of participation of network partners and create new concepts, values and rules in the professional activities of mediators, including in the context of digital transformation.

Let me summarise some preliminary results of the studies presented in the works by the following authors.

The advantages of distance learning and electronic support for students in training future mediators are presented in the work "Strategic Upgrade of the Master's Program "Mediation in Education" in a Digital Transformation Context" by Smolyaninova O.G., Ivanov N.A. and Egle E.S. The authors note that the upgrade of the master's programme for mediators' training at Siberian Federal University is associated not only with digital transformation, which turned out to be especially relevant in the context of the pandemic, but also with the development of the network partnership of universities of Siberia and Kazakhstan, with the involvement of practicing mediators from professional communities. The authors 
present mechanisms for providing electronic support for a master's programme that contribute to the expansion of the didactic potential of e-learning and describe the organisational and pedagogical conditions for the effective use of the university's electronic environment, social media and open educational platforms. The efficiency of the mechanism of systemic electronic support developed and implemented by the authors is confirmed by the results of the psychological and pedagogical experiment on assessment of personal traits and professional competencies of undergraduates trained within the framework of the model declared by the authors.

In the context of total digitalisation of social and economic processes, special requirements are imposed on digital literacy and digital competence of teachers. The European Digital Competence Framework (2018) identifies six blocks for teachers: professional responsibilities; digital resources; teaching and learning; student assessment; empowerment of students' rights, opportunities and students' autonomy in the educational process; development of digital competence of students. In this regard, digitalisation of the institution of mediation is one of the trends in the development of mediation practices.

The article by Ermolovich E.V. and Timoshkov A.V. is devoted to the study of the digital competence of a mediator as a necessary component of professional activities. The professional standards of a mediation specialist have been analysed. The authors propose a model of digital competence of a mediator in education, which includes professional level in addition to the basic one: online mediation, prevention of conflicts in a virtual environment and information and psychological security. The authors investigate the digital competence indices of practicing mediators in Siberia and propose mechanisms for improving the model of training undergraduates at Siberian Federal University.

A logical continuation of developing the mediators' digital competence model is "Specification of the restorative mediation practices online" offered by a famous Russian practicing mediator Anton $\mathbf{Y u}$. Konovalov.
The author brings up to date the problems of increasing tension and anxiety of minors who have found themselves in forced isolation and confined space at home during the pandemic. An increase in the level of the nervous mood among adults and minor children leads to an increase in the number of family and child-parental conflicts. The article by Anton Konovalov offers ideas and recommendations for conducting restorative mediation online. The author's conceptual conclusion is that online mediation technologies are promising not only in the context of total threats and the pandemic, but also in working with conflict actors in closed institutions: hospitals, temporary detention centres, places of detention, homeschooled students and their parents, patients in medical institutions and other conflict participants who do not want or do not have the opportunity to communicate in real space.

In our opinion, adolescents with deviant behaviour also belong to such a category of potential clients for online mediation in resolving conflicts. Novosibirsk scientists - psychologists O.O. Andronnikova, O.E. Radzikhovskaya investigate the specificity of the attitude to the school mediation service of students with deviant behaviour. On the basis of the comparative analysis of the difference in the perception of mediation practices by various groups of adolescents, the authors note a positive perception of adolescents who have mediation experience in relation to mediation technology as a means of resolving conflicts and developing interpersonal interaction skills, as a means of self-development and self-understanding.

Saule Shunkeyeva, Bakytgul Zhetpisbayeva, Gulnara Smagulova, Lyailya Syrymbetova, Dmitriy Dyakov in the article "English Language's Functioning in the Students' Microcommunity: A Case of Kazakhstan" study the peculiarities of the English language functioning in the students' microcommunity in the conditions of multilingualism in Kazakhstan. The research methodology is based on the concepts of sociological and interactional (socially conditioned) communicative and theoretical sociolinguistics. The main results of the study are the authors' position on the conditionality of individual and personal 
motivation of language speakers in the student microcommunity associated with the specificity of the language situation in Kazakhstan, due to the co-functioning of two languages - Kazakh and Russian - in a single communicative space. Let us add that in our opinion mediation technologies in resolving conflicts in education in the conditions of a multilingual multiethnic society in Kazakhstan have great prospects due to state support of the policy of three languages.

The article "Conflicting identities and subjective well-being in the frontier regions of Russia" by Anna V. Nemirovskaya, a researcher at the Higher School of Economics, presents a large-scale sociological study of indicators of subjective well-being and territorial social identity in the frontier and central regions of Russia. The analysis examines factors of socio-economic, socio-demographic, psychological and cultural nature. The author notes the influence of the frontier history of settlement and border location on various socio-cultural and socio-political characteristics of regional communities, and thus on the social identities of people living in the frontier regions of Russia. Well-known Russian sociologist Anna Nemirovskaya has identified a number of significant differences in the frontier and central regions. In particular, the significance of the predictor of social cohesion for the frontier regions of Russia, while for the central regions it is the significance of the factors of age and religiosity in life satisfaction.

In the study by Moscow scientists of the Russian Academy of Education Yulia V. Slobodchikova, Irina V. Semchuk, Elena V. Skvortsova, Oksana A. Musatova, based on the methods of logical, theoretical, comparative and content analysis, the most significant personality determinants of increasing the effectiveness of sports among young people were determined. The authors propose a theoretical structural-functional psychological model of the personality determinants of young people. In our opinion, the model proposed by the authors and the identified essential relationships of intrapersonal structures mediating the process of influence of biological, social and individual determinants of personality on increasing the effectiveness of sports among young people can be adapted and used to diagnose the effectiveness of specialists in other professions, in particular mediators. Of course, with a different specification of significant personality traits and professional competencies of mediators.

\section{Conclusion}

In conclusion, let us once again emphasise the importance of developing models for training mediators for the education system in the new conditions of digital transformation with a special focus on online mediation, as well as the understanding of the new social functions of mediators in a global multinational and multilingual society. According to Mark Davidheiser (Davidheiser, 2005), a modern mediator must have competencies at three levels: 1) the mediating role of cultural instruments, in particular language and curriculum in schools, 2) the role of peers and teachers in the appropriation of cultural instruments by minority students, and (3) the mediating role of social representations in the formation of students' identity at school.

This analytical review presents a new vision of the possible positions of the leading scientists in Siberia, central regions of Russia and Kazakhstan. Conflict problems in the system of multicultural education are unusually multifaceted and complex. Mediation technologies for solving problems posed by destructive conflicts will require large-scale efforts. It is obvious that in the short- and long-term perspective, the general line of development of mediation will be the integration of online and offline forms and methods of productive communication and organisation of negotiations. Therefore, the central task is to combine the theory and practice of conflict resolution technology, taking into account socio-cultural characteristics, contextual situations, regional and national specificity of individual territories, and the socio-economic situation. The latter determines immediate and distant prospects for the development of mediation in education for resolving conflicts at all levels, taking into account the experience gained in the context of the pandemic and new challenges of fatal threats. 


\section{Acknowledgements}

I am particularly grateful for the financial support of innovative ideas, research and practical developments in terms of the projects which allowed to unite the efforts of researchers, practical specialists and enthusiasts of mediative technology in Russia and Kazakhstan:
Russian Foundation for Basic Research (RFFR) for 3-year long support of our initiatives and research within the project No. 18013-00528 "The study of mediation practices in the field of education for harmonization of interethnic relations in a multicultural environment".

\section{References}

Allakhverdova, O.V. (2012). Obuchenie mediatorov i formirovanie kompetencii [Training Mediators and Forming Competencies]. In Vestnik Sankt-Peterburgskogo universiteta. Psikhologiia [Vestnik of Saint Petersburg University. Psychology], 3, 51-59.

Belonogova, E.V., Prokopyeva, N.G. (2020). Algorithms for Mediation Restorative Work of the Territorial Reconciliation Service in Difficult Cases. In Journal of Siberian Federal University. Humanities and Social Sciences, 13 (2), 179-190. DOI: 10.17516/1997-1370-0549.

Davidheiser, M. (2005). Mediation and Multiculturalism: Domestic and International Challenges. Available at: https://www.beyondintractability.org/essay/mediation_multiculturalism (accessed 21 August 2020).

Iamburg, E.A. (2020). Avgustovskie tezisy k pedsovetu [August readings to the teachers' council]. In Uchitel'skaia gazeta, 33, available at: http://ug.ru/archive/84508

Shamlikashvili, Ts.A. (2013). Osnovy mediatsii kak protsedury uregulirovaniia sporov. Uchebnoe Posobie [Fundamentals of Mediation as a Dispute Resolution Procedure]. Moscow, MCUPK, 128 p.

Smolyaninova, O. (2018). Mediation Practices in Education: Intercultural Context of Multinational Siberia. Proceedings 10th International Conference on Education and New Learning Technologies. Palma, 3862-3867.

Zhbankova, N.V., Prokhorova, O.A. (2017). Emotsional'nyi intellekt kak kognitivnaia kompetentsiia mediatora [Emotional Intelligence as the Cognitive Competence of the Mediator]. In Kazanskaia nauka [Kazan Science], 11, 83-86. 


\title{
Конфликты и медиация в мультикультурном социуме: \\ психолого-педагогические и социологические аспекты
}

\author{
О.Г. Смолянинова \\ Сибирский федеральный университет \\ Российская Федеращия, Красноярск
}

\begin{abstract}
Аннотация. Данная статья представляет аналитический обзор психологопедагогических и социологических аспектов разрешения конфликтов с использованием медиации в поликультурном социуме, который построен на анализе и обобщении исследований, представленных в материалах данного выпуска журнала. Анализ теории и практики разрешения конфликтов, личностных детерминант поведения молодежи, форматов и моделей подготовки медиаторов для системы образования разворачивается в полипарадигмальном и междисциплинарном контекстах и является результатом совокупных усилий педагогов, практикующих медиаторов, юристов, психологов, социологов. В материалах этого выпуска журнала представлены исследования по нескольким тематическим блокам: модели подготовки медиаторов; практики медиации в формате онлайн; профессиональные и этические стандарты медиатора; социологические исследования социальных идентичностей в регионах российского фронтира, социологические исследования коммуникативно-языкового пространства Республики Казахстан в условиях полилингвизма; психолого-педагогические исследования личностных детерминант молодежи; анализ цифровых компетенций медиатора и модели электронного сопровождения магистрантов в условиях цифровой трансформации.
\end{abstract}

Ключевые слова: конфликты, мультикультурный социум, медиация, онлайнмедиация, полилингвизм, личностные детерминанты, восстановительный подход, социальная идентичность, профессиональная компетентность медиатора, цифровая трансформация.

Научные специальности: 13.00 .00 - педагогические науки; 22.00 .00 социологические науки. 